\title{
E1A signaling to $p 53$ involves the p19ARF tumor suppressor
}

\author{
Elisa de Stanchina, ${ }^{1}$ Mila E. McC urrach, ${ }^{1}$ Frederique Zindy, ${ }^{2}$ Sheau-Yann Shieh, ${ }^{3}$ Gerardo Ferbeyre, ${ }^{1}$ \\ Andrew V. Samuelson, ${ }^{1}$ Carol Prives, ${ }^{3}$ Martine F. Roussel, ${ }^{2}$ Charles J. Sher, ${ }^{2,4}$ and Scott W. Lowe ${ }^{1,5}$
}

${ }^{1}$ Cold Spring Harbor Laboratory, Cold Spring Harbor, N ew York 11724 USA; ${ }^{2}$ Department of Tumor Cell Biology and ${ }^{4}$ Howard Hughes Medical Institute, St. Jude Children's Research Hospital, M emphis, Tennessee 38105 USA; ${ }^{3}$ Department of Biological Sciences, Columbia University, N ew York, N ew York 10027 USA

\begin{abstract}
The adenovirus E1A oncogene activates $\mathrm{p} 53$ through a signaling pathway involving the retinoblastoma protein and the tumor suppressor p19ARF. The ability of E1A to induce p53 and its transcriptional targets is severely compromised in ARF-null cells, which remain resistant to apoptosis following serum depletion or adriamycin treatment. Reintroduction of p19ARF restores $\mathrm{p} 53$ accumulation and resensitizes A RF-null cells to apoptotic signals. Therefore, $\mathrm{p19} \mathrm{ARF}^{\mathrm{RF}}$ functions as part of a p53-dependent failsafe mechanism to counter uncontrolled proliferation. Synergistic effects between the p19ARF and DNA damage pathways in inducing p53 may contribute to E1A's ability to enhance radio- and chemosensitivity.
\end{abstract}

[Key Words: E1A signaling; p53; p19ARF tumor suppressor]

Received June 23, 1998; accepted in revised form June 29, 1998.

Tumor-specific mutations identify genes essential for normal growth control and reveal fundamental processes involved in tumorigenesis. Similarly, viral oncoproteins target cellular protei ns critical for malignant transformation-often the same activities altered by spontaneous mutation in cancer cells. For example, many DNA tumor viruses encode proteins that bind and inactivate both p53 and the retinoblastoma (Rb) protein, and inactivation of both is essential for viral transformation (Lane and Crawford 1979; Linzer and Levine 1979; DeCaprio et al. 1988; Whyte et al . 1988a; Dyson et al. 1989; Werness et al. 1990). Consistent with the relevance of these interactions, p53 and Rb are frequently mutated in human tumors (for review, see Greenblatt et al. 1994; Weinberg 1995).

Although the high frequency of p53 mutations in human cancer implies a central role for p53 in tumorigenesis, the signals that trigger p53 in suppressing tumor growth remain poorly defined. p53 is a sequence-specific DNA-binding protein that promotes cell-cycle arrest or apoptosis in response to a variety of cellular stresses (for examples, see Kastan et al. 1991; Graeber et al. 1994; Linke et al. 1996; for review, see Ko and Prives 1996; Levine 1997). For example, p53 levels and activity increase following DN A damage owing, in part, to de novo phosphorylation and the accompanying conformational changes (Shieh et al. 1997; Siliciano et al. 1997). Phos-

${ }^{5}$ Corresponding author.

E-MAIL lowe@cshl.org FAX (516) 367-8454. phorylation at serine-15 prevents p53's interaction with M dm2 (Shieh et al. 1997), a protein that can down-regulate p53 via ubiquitin-mediated proteolysis (Haupt et al. 1997; Kubbutat et al. 1997). In principle, failure of p53 to suppress proliferation following DN A damage might indirectly promote tumor development by allowing the growth and survival of cells with mutations (Livingstone et al. 1992; Yin et al. 1992; Griffiths et al. 1997), but whether this provides the primary driving force for $\mathrm{p} 53$ mutation in tumors is unclear.

Oncogenes can also induce p53, leading to increased apoptosis or premature senescence (Lowe and Ruley 1993; Hermeking and Eick 1994; Wagner et al. 1994; Serrano et al. 1997). For example, the adenovirus E1A oncogene induces p53 and promotes apoptosis in primary cells (Debbas and White 1993; Lowe and Ruley 1993; Querido et al. 1997; Samuelson and Lowe 1997), which is reflected by E1A's remarkable ability to enhance radioand chemosensitivity (Lowe et al. 1993). Although E1A is a mitogenic oncogene, p53 acts to limit its oncogenic potential. Thus, p53-deficient primary fibroblasts expressing E1A are resistant to apoptosis and become oncogenically transformed (Lowe et al. 1994b). Two E1A domains act in concert to promote p53 accumulation and apoptosis in primary cells; the first inactivates $\mathrm{Rb}$, whereas the second binds the $\mathrm{p300/CBP}$ transcriptional coactivators (Samuelson and Lowe 1997). Interestingly, the integrity of both domains is required for E1A's oncogenic potential (Whyte et al. 1988b, 1989). The ability of E1A to activate p53 is not unique, as c-Myc activates p53 to promote apoptosis (Hermeking and Eick 1994; 
E1A activates $p 53$ via p19ARF

Wagner et al. 1994) and oncogenic ras induces p53 leading to premature senescence (Serrano et al. 1997). How oncogenic signals activate p53 is not known, al though it is conceivable that they induce p53 by inadvertently damaging DNA. N evertheless, the general involvement of p53 in the cellular response to oncogenes raises the possibility that these stimuli are fundamental to p53's tumor suppressor activity.

The INK4a/ARF locus is second only to p53 in the frequency of its disruption in human cancer (for review, see Haber 1997). This locus encodes p16 ${ }^{\text {IN K4a }}$, a cyclin-dependent kinase inhibitor (CDKI) that acts upstream of $\mathrm{Rb}$ to promote cell-cycle arrest (Serrano et al. 1993). Although compelling evidence indicates that $\mathrm{p} 16^{\mathrm{INK} 4 \mathrm{a}}$ is an important tumor suppressor, the INK4a/ARF locus encodes a second protein translated in an al ternate reading frame, desi gnated p19ARF (Quelle et al. 1995). p $19^{A R F}$ and $p 16^{\text {IN K4a }}$ are often codeleted in tumor cells, but mice lacking p19 ${ }^{A R F}$ al one are highly cancer prone (Kamijo et al. 1997; for review, see Haber 1997). p19ARF promotes cell-cycle arrest (Quelle et al. 1995), whereas ARF-null primary mouse embryo fibroblasts (MEFs) do not undergo replicative senescence and are transformed by oncogenic ras alone (Kamijo et al. 1997). Thus, ARF is a bona fide tumor suppressor.

p19ARF may function in a genetic and biochemical pathway that involves p53. At the organismal level, the consequences of deleting p53 and ARF are remarkably similar (Donehower et al. 1992; Kamijo et al. 1997). In either case, the mutant mouse devel ops normally but is highly predisposed to malignant tumors of a similar overall pattern and latency. At the cellular level, enforced expression of p19 ${ }^{\mathrm{ARF}}$ can induce cell-cycle arrest in cells harboring wild-type but not mutant p53 (Kamijo et al. 1997). In turn, p19ARF can physically associate with p53 itself and/or Mdm2 to alter p53 levels and activity (Kamijo et al. 1998; Pomerantz et al. 1998; Zhang et al. 1998). N evertheless, ARF is not required for the p53 response following DNA damage, as radiation induces $G_{1}$ arrest in ARF-deficient fibroblasts and apoptosis in ARFdeficient thymocytes (Kamijo et al. 1997, 1998). Thus, an understanding of the signals that activate p19ARF may help to explain its role as a tumor suppressor as well as that of p53.

In this study we compared the mechanism whereby DNA damaging agents and the EIA oncogene activate p53. We demonstrate that E1A activates p53 through a fundamentally different mechanism than DNA damage, which is dependent on the presence of p19ARF. Furthermore, si multaneous activation of p53 through oncogenes and DNA damage synergize to promote apoptosis and thereby enhance radio- and chemosensitivity. These data imply that p19ARF acts to suppress tumor growth in response to hyperproliferative signals. Conversely, as p19ARF mediates activation of p53 by an oncogene and is frequently lost in human tumors, these data strongly support the view that p53's tumor suppressor activity can arise from its ability to el iminate oncogene-expressing cells.

\section{Results \\ E1A and DNA damage induce p53 through distinct mechanisms}

The E1A oncogene induces p53 through a mechanism involving inactivation of $\mathrm{Rb}$ gene product, and up-regulation of p53 correlates with the ability of E1A to promote apoptosis (Lowe and Ruley 1993; Lowe et al . 1994b; Samuelson and Lowe 1997). DNA damage produced by radiation and certain cytotoxic drugs also activates p53, at least in part, through a kinase that phosphorylates p53 on serine-15 (Shieh et al. 1997; Siliciano et al. 1997). To determine whether DNA damage and E1A induce p53 through similar mechanisms, we examined the phosphorylation status of p53 on serine-15 in cells expressing or lacking E1A. E1A was introduced into normal diploid human fibroblasts (IMR90 cells) by retroviral-mediated gene transfer. After a 3-day drug selection to eliminate uninfected cells, p53 levels and phosphorylation status were assessed by Western blot analysis using antibodies that recognize total p53 or only that fraction phosphorylated on serine-15 (Shieh et al. 1997; Siliciano et al. 1997). For comparison, IMR90 cells were treated with ionizing radiation or with the calpain/proteosome inhibitor LLnL, both of which are also known to stabilize p53 (Maki et al. 1996). Total p53 was examined by Western blotting; al ternatively, p53 was immunoprecipitated and scored for the presence of serine-15 phosphate using antibodies that detect this epitope.

As expected, ionizing radiation produced a large increase in p53 protein (Fig. 1A, Iane 2) accompanied by p53 phosphorylation on serine 15 (Fig. 1B, lane 2). LLnL also induced p53 but without serine-15 phosphorylation (Fig. 1, A, lane 3, and B, lane 1). E1A produced even greater increases in p53 levels (Fig. 1A, lane 4) without detectable phosphorylation of p53 on serine 15 (Fig. 1B, lane 3). However, E1A did not inhibit p53 phosphorylation on serine-15, as $\gamma$-irradiation of cells expressing E1A produced little, if any, additional increase in p53 protein (Fig. 1A, lane 5) but led to a marked increase in antiphosphoserine-15 reactivity (Fig. 1B, lane 5). Induction of p53 in the absence of serine-15 phosphorylation argues that E1A does not produce DN A damage indirectly but, rather, suggests that $E 1 A$ and ionizing radiation activate p53 through distinct mechanisms.

E1A induces p19ARF through domains required for p53 accumulation and apoptosis

Enforced expression of p19ARF stabilizes p53 and arrests proliferation in a p53-dependent manner, yet ARF is not required for radiation-induced cell-cycle arrest or apoptosis (Kamijo et al. 1997; Pomerantz et al. 1998; Zhang et al. 1998). The fact that E1A al so stabilizes p53 through a DNA damage-independent mechanism is consistent with the possibility that ElA acts through p19ARF to induce p53. E1A or various E1A mutants were introduced into primary MEFs, and p19ARF expression was monitored 3 days later. E1A caused a dramatic induction of p19ARF, correlating with p53 accumulation (Fig. 2, A 


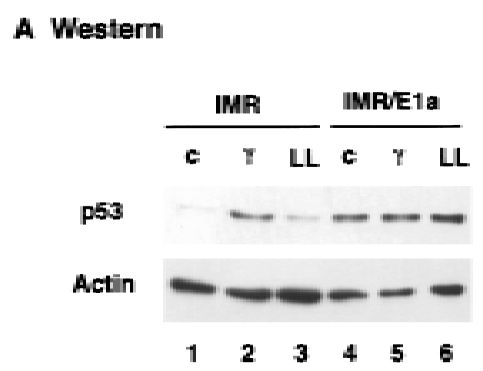

B IPMestern

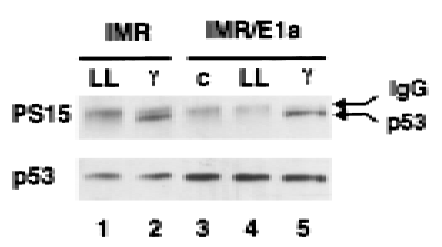

Figure 1. E1A induces $p 53$ in the absence of phosphorylation on serine-15. IMR90 fibroblasts were infected with control (IM R) or E1A-expressing (IM R/E1A) retroviruses. Extracts were prepared from untreated cells (c), or from cells treated $3 \mathrm{hr}$ earlier with $7 \mathrm{~Gy} \gamma$ radiation $(\gamma)$ or $2 \mathrm{hr}$ earlier with $50 \mu \mathrm{M} \mathrm{LLnL}$ (LL). (A) p53 levels were determined by Western blot analysis using pAb 1801 and DO1. Equal loading of the gel was confirmed by stripping the blot and reprobing with anti- $\beta$-actin antiserum. (B) p53 was immunoprecipitated from extracts corresponding to $100 \mu \mathrm{g}(\mathrm{IMR})$ or $35 \mu \mathrm{g}$ (IMR/E1A) total protein using pAb 1801, and Western blots were probed with antibodies specific for p53 phosphoserine-15 ( $\alpha$ p53-P-Ser-15).

and B, cf. lanes 2 and 1). A similar increase was also observed in ARF mRNA expression, indicating that E1A was affecting $A R F$ transcription or message stability (Fig. 2B, cf. lanes 2 and 1). As demonstrated previously (Kamijo et al. 1997), ARF is constitutively upregulated in $\mathrm{p53}^{-1-}$ MEFs (Fig. 2B, lane 5), suggesting the presence of a negative feedback loop. However, E1A still induced p19ARF expression in p53-deficient cells (two- to threefold), implying that p53 is not required for p19 ${ }^{A R F}$ upregulation by E1A (Fig. 2B, lane 6).

E1A associates with a series of cellular proteins, including Rb, the Rb-related proteins p107 and p130, and the transcriptional coactivators $\mathrm{p} 300$ and CBP (for review, see Flint and Shenk 1997). E1A mutants unable to bind either p300/CBP (E1A $\Delta N$ ) or the Rb-family proteins (E1A $\triangle C R 2$ ) were impaired in their ability to induce p19ARF and p53 (Fig. 2A, lanes 3,4), implying that E1A's ability to bind both sets of cellular proteins is required for maximal p19ARF accumulation. In agreement, p19ARF protein induction was restored in cells coinfected with both E1A mutants (data not shown). p19ARF levels were slightly el evated in Rb-deficient MEFs (Fig. 2A, lane 5) although this difference was more pronounced in later passage MEFs (data not shown; see al so Zindy et al. 1998). Importantly, p19ARF levels were further increased by expression of E1A (Fig. 2A, lane 6) or, in contrast to normal cells, the E1A $\triangle \mathrm{CR} 2$ mutant (Fig. 2A, cf. lanes 4 and 8). However, p19ARF was not elevated in p107- and p130-deficient MEFs, nor was it induced by E1A $\triangle$ CR2 (data not shown). Thus, among the Rb-family proteins that bind $E 1 A$, the recognized ability of E1A to inactivate $\mathrm{Rb}$ solely contributes to $\mathrm{p} 19^{\mathrm{ARF}}$ accumulation. These data demonstrate that at least two E1A functions contribute to p19ARF induction: inactivation of $R b$ and, possibly, binding to p300/CBP. N otably, these are the same domains of E1A that are necessary for its ability to induce p53 and promote apoptosis (Samuelson and Lowe 1997).

\section{ARF promotes $p 53$ accumulation in response to $E 1 A$}

p53 activation is typical ly accompanied by increased expression of its transcriptional targets, including p21 and Mdm2. p21 is a CDKI involved in p53-dependent cellcycle arrest (El Deiry et al. 1993; Harper et al. 1993; Xiong et al. 1993). $M$ dm2 acts in a negative feedback loop to down-regulate p53 and is expressed from two promoters, one of which is regulated by p53 (Barak et al. 1993,

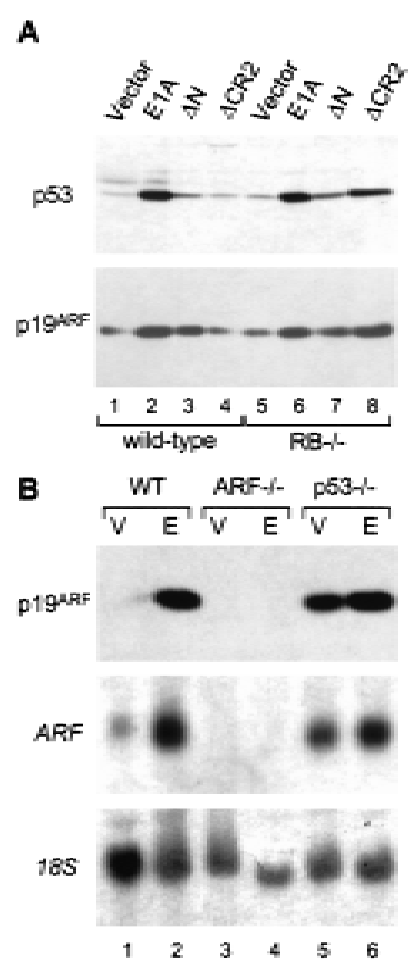

Figure 2. $E 1 A$ induces $p 19^{A R F}$ and $p 53$ through a similar mechanism. (A) Early passage (about three to four) wild-type and $\mathrm{Rb}^{-1-} \mathrm{MEFs}$ from littermates embryos were infected with retroviruses expressing full-length E1A or E1A mutants unable to bind $\mathrm{p} 300 / \mathrm{CBP}(\Delta \mathrm{N})$ or the Rb-related proteins $(\Delta \mathrm{CR} 2)$. An empty retroviral vector was used as a control (vector). Immunoblotting was performed using polyclonal antibodies against p19ARF or p53. Using this procedure, each E1A mutant is efficiently expressed at comparable levels (Samuel son et al. 1997). (B) Wild-type (WT), ARF-null ( $\mathrm{ARF}^{-1}$ ), and p53-null ( $\mathrm{p53}^{-1}$ ) $M E F s$ were infected with a control vector $(V)$ or a retrovirus expressing full-length EIA (E). Lysates were derived from whole populations passaged minimally in culture ( $<1$ week) and analyzed for ARF protein (top) or mRNA (middle) expression by Western or Northern blotting, respectively. Northern blots were rehybridized using a probe to the $18 \mathrm{~S}$ rRN A to confirm equal loading (bottom). 
1994; Wu et al. 1993). To determine whether ARF is required for p53 induction by E1A, the expression of p53, p21, and $M d m 2$ were examined in wild-type, $A \mathrm{RF}^{-1-}$, and p53 ${ }^{-1-M E F s . ~ I n ~ w i l d-t y p e ~ M E F s, ~ E 1 A ~ i n c r e a s e d ~ p 53 ~}$ protein expression, which was accompanied by accumulation of p21 and several forms of M dm2 (Fig. 3A, Iane 2). Induction of p21 and Mdm2 was p53-dependent, as neither protein was induced by E1A in p53-deficient cells (Fig. 3A, lane 6). Remarkably, expression of equivalent levels of E1A did not induce p53 in ARF-deficient cells, nor affect its targets p21 and Mdm2 (Fig. 3A, lane 4). Of note, wild-type and $A \mathrm{RF}^{-1-} \mathrm{MEFs}$ infected with a control vector displayed similar p53 levels, indicating that p19ARF loss does not markedly affect basal p53 expression (compare lanes 1 and 3). Therefore, ARF facilitates the up-regulation of p53 protein and its associated transcriptional activity following expression of E1A.

When activated by DN A damage, $M d m 2$ is induced as part of a negative feedback loop that facilitates p53 degradation. However, wild-type MEFs expressing E1A accumulate p53 despite a large increase in Mdm2 levels

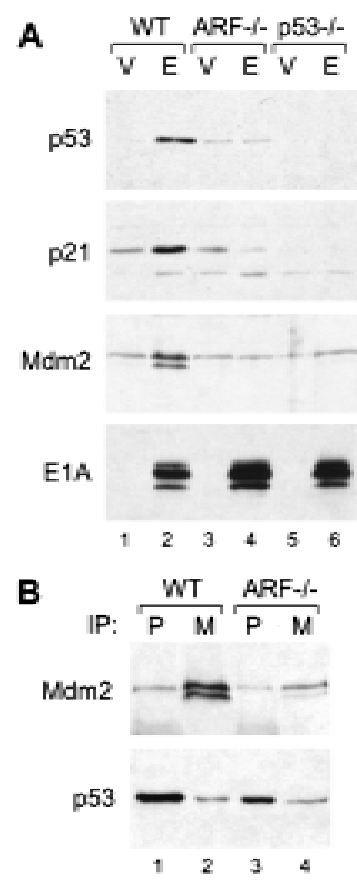

Figure 3. $p 19^{A R F}$ mediates $p 53$ induction by E1A and interferes with the p53/Mdm2 interaction. Wild-type (WT), ARF-null $\left(\mathrm{ARF}^{-1}\right)$ and $\mathrm{p} 53-$ null $\left(\mathrm{p} 3^{-1}\right)$ cell populations harboring a control vector $(\mathrm{V})$ or expressing E1A (E) were prepared by retroviral gene transfer. Protein expression was analyzed in whole cell populations passaged minimally in culture ( $<1$ week). (A) p53 protein levels al ong with the levels of its transcriptional targets p21 and Mdm2 were determined by immunoblotting. (B) $\mathrm{Mdm} 2 / \mathrm{p} 53$ complexes were examined in wild-type and ARFnull populations expressing E1A by immunoprecipitation with monoclonal antibodies directed against p53 (P) or Mdm2 (M), followed by immunoblotting with a polyclonal rabbit antibody against p53. The blots were then reprobed using the same monoclonal antibody against $\mathrm{Mdm} 2$. N ote that the p53 blot was overexposed to allow visualization of the amount associated with Mdm2. (see Fig. 3A, lane 2). We examined the ability of M dm2 to associate with p53 in MEFs expressing E1A by use of sequential immunoprecipitation and Western blotting. Despite the fact that wild-type MEFs expressing E1A displayed an 10-fold increase in p53 and Mdm2 levels as compared to their ARF-defici ent counterparts, the absolute amount of $\mathrm{Mdm} 2$ bound to p53 was comparable in both cell types (Fig. 3B, cf. p53, lanes 2 and 4). Thus, p53 associates poorly with $\mathrm{Mdm} 2$ in wild-type cells expressing E1A. This implies that p19ARF, either directly or indirectly, contributes to p53 accumulation by preventing Mdm2-mediated degradation of p53 (Pomerantz et al. 1998; Zhang et al. 1998).

\section{Inactivation of ARF attenuates apoptosis}

E1A sensitizes primary fibroblasts to apoptosis induced by diverse stimuli, including serum depletion and treatment with chemotherapeutic drugs. The fact that ARFdeficient cells are unable to induce p53 in response to E1A suggests that $A R^{-1-}$ MEFs expressing E1A might be resistant to apoptosis. Consistent with this possibility, the ability of Rb deficiency to trigger apoptosis was attenuated in developing mouse lenses disrupted for both ARF and INK4a (Pomerantz et al. 1998). Therefore, we compared the sensitivity of various virus-infected populations to cell death following serum withdrawal and treatment with adriamycin, a chemotherapeutic drug that produces double-stranded DNA breaks (Ross and Bradley 1981) and induces p53-dependent apoptosis in this setting. Two criteria were used to monitor apoptosis: annexin $\mathrm{V}$ staining followed by flow cytometry to assay membrane changes, and DAPI staining foll owed by fluorescence microscopy to visualize the characteristic chromatin condensation in apoptotic cells.

Concordant with previous results, wild-type MEFs expressing E1A lost viability following serum depl etion or adriamycin treatment, whereas p53 ${ }^{-1-}$ MEFs expressing E1A did not (Fig. 4A,B). ARF ${ }^{-1}-M E F s$ were significantly more resistant to $E 1 A$-induced apoptotic signal s as compared to their wild-type counterparts but were somewhat more sensitive than cells lacking p53. In all cases, cell death was due to apoptosis, as measured by annexin $\mathrm{V}$ binding as well as chromatin condensation (Fig. 4C). Uninfected MEFs of all genotypes remained viable following serum depletion or adriamycin treatment at these doses, indicating that E1A was required for apoptosis under these conditions (data not shown). Therefore, p19ARF contributes to p53's apoptotic potential in cells expressing E1A. However, the fact that p53 loss is more protective than ARF loss implies that some apoptotic signals address p53 through a p19 ${ }^{A R F}$-independent pathway. For example, adriamycin might al so exert some of its effects through the DN A damage pathway (see below).

If ARF loss protects cells from apoptosis in a p53-dependent manner, a clear prediction is that reintroduction of ARF into ElA-expressing cells containing wild-type p53 should resensitize them to the effects of serum deprivation and adriamycin. Conversely, cells lacking p53 should be unaffected by ARF. Hemagluttinin (HA)- 
Figure 4. E1A-expressing cells lacking ARF are defective in apoptosis. Wild-type (๑), ARFnull ( $(\mathbf{\Delta})$, and p53-null ( $\boldsymbol{\square}$ ) early passage MEFs were infected with control retroviruses (not shown) or retroviruses expressing E1A. Within a week of gene transfer, the resulting cell populations were examined for cell death at various times following serum depletion (A) or $24 \mathrm{hr}$ after treatment with the indicated doses of adriamycin (B). Cell viability was assessed by trypan blue exclusion. Each point represents the mean \pm S.D. from at least three separate experiments. Fibroblasts of all genotypes infected with a control vector retained viability $(>90 \%)$ following serum depletion or adriamycin treatment (data not shown). (C) Wildtype (WT), ARF-null (ARF-1-) and p53-null (p53 $3^{-1}$ ) MEFs expressing E1A were examined for apoptosis $18 \mathrm{hr}$ after transfer to $0.1 \%$ serum conditions. Annexin $\mathrm{V}$ binds phosphotidylserine. A poptotic changes in membrane biochemistry lead to increased concentration of phosphotidylserine on the outer plasma membrane, where it becomes accessible to annexin V (An-


C
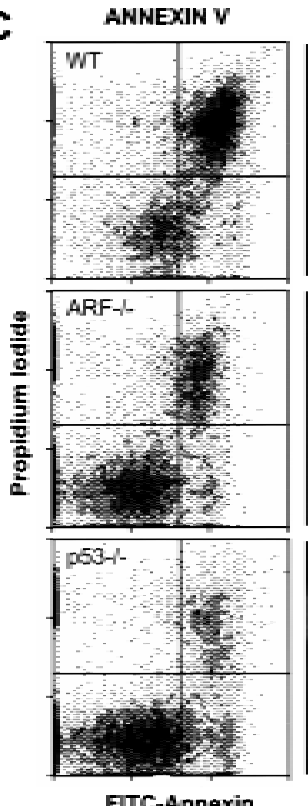

DAPI
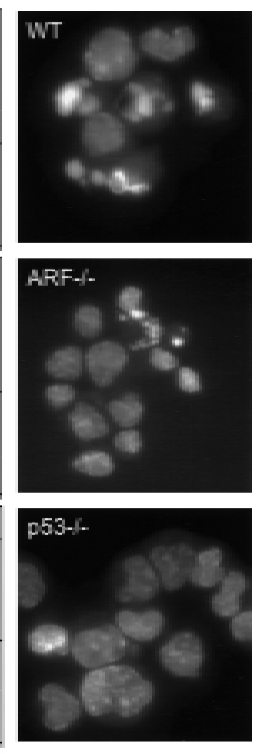

dree et al. 1990). Propidium iodide fluorescently stains late apoptotic cells that have lost membrane integrity. Shown are representative dot plots from two-color flow cytometry: (Bottom left quadrant) Viable; (bottom right quadrant) early apoptotic; (top right quadrant) late apoptotic. DAPI staining al lows visualization of the chromatin condensation characteristic of apoptotic cells. $\mathrm{N}$ ote that there was little apoptosis in E1A-expressing populations in $10 \%$ serum nor in vector-only control populations in $0.1 \%$ serum (data not shown).

tagged ARF was introduced by retroviral gene transfer into wild-type, $\mathrm{ARF}^{-1-}$, and $\mathrm{p} 53^{-1-M}$ EFs expressing $\mathrm{E} 1 \mathrm{~A}$. Cells were infected at high multiplicity to bypass a need for drug selection. Exogenous p19ARF expression caused a 5- to 10-fold increase in p53 expression in both wildtype and $A_{R F}^{-1-M E F s ~ e x p r e s s i n g ~ E l A ~(F i g . ~ 5 A), ~ c o n s i s-~}$ tent with previous results (Kamijo et al. 1997, 1998). E1A-expressing wild-type MEFs infected with a control vector did not undergo apoptosis in high serum conditions but upon transfer to low serum conditions, underwent similar levels of apoptosis as uninfected E1A-expressing MEFs (Fig. 5B). As shown above (see Fig. 4), vector-infected cells lacking ARF or p53 were resistant to apoptosis when transferred to serum-depleted medium (Fig. 5B). Following infection with ARF retrovirus, both wild-type and $\mathrm{ARF}^{-1}-\mathrm{MEFs}$ expressing E1A displayed a modest increase in apoptosis when maintained in serum and underwent massive apoptosis upon serum depletion. Importantly, the same levels of exogenous p19ARF had little effect on $\mathrm{p5}^{-1-}$ MEFs (Fig. 5B). Hence, depending upon the growth conditions, p19ARF can act upstream of p53 to induce either cell cycle arrest (Kamijo et al . 1997) or apoptosis. The fact that restoration of ARF function can resensitize $A \mathrm{RF}^{-1-} \mathrm{MEFs}$ to the combined effects of E1A and low serum provides compelling evidence that attenuation of apoptosis in $\mathrm{ARF}^{-1-}$ cells is a direct consequence of ARF loss and not due to additional genetic changes.

Synergy between p19ARF-dependent and -independent pathways targeting p53

Because DNA damage and E1A can activate p53 through
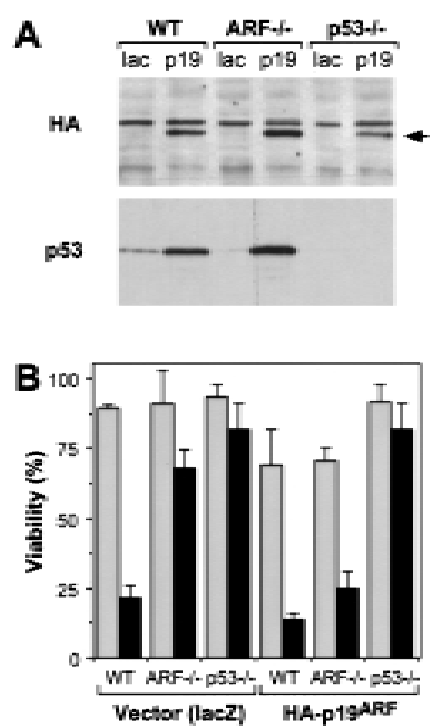

Figure 5. Reintroduction of $19^{\mathrm{ARF}}$ restores apoptosis. Control and E1A-expressing populations derived from wild-type (WT),

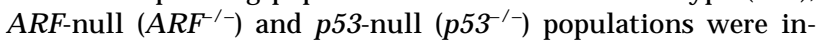
fected with retroviruses expressing lacZ or an HA-tagged ARF CDNA (Quelle et al. 1995). Thirty-six hours later, the resulting cell populations were analyzed for p53 and exogenous p19ARF protein expression or treated with apoptotic stimuli. (A) Immunoblotting of infected populations using a monoclonal antibody recognizing the $\mathrm{HA}$ epitope fused to $\mathrm{p} 19^{\mathrm{ARF}}$ or a polyclonal antibody directed against p53. The arrow denotes the migration of $\mathrm{HA}$-tagged p19ARF. (B) The indicated cell populations were placed in $10 \%$ (shaded bars) or $0.1 \%$ (solid bars) serum for $24 \mathrm{hr}$ and cell viability was measured by trypan blue exclusion. The values represent the mean and S.D. of at least three separate infections. 

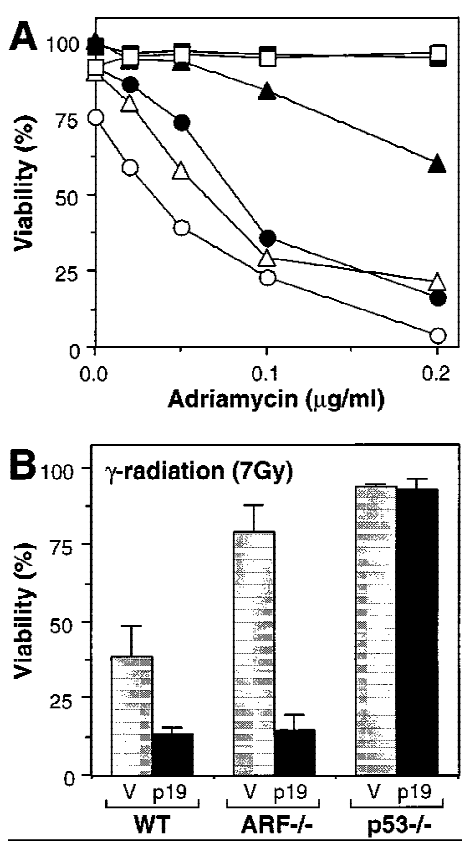

Figure 6. Synergy between $\mathrm{p} 19^{\mathrm{ARF}}$-dependent and -independent pathways targeting p53. (A) lacZ (solid symbols)- and HAARF (open symbols)-expressing cell populations were treated with the indicated doses of adriamycin, and cell viability was determined $24 \mathrm{hr}$ later by trypan blue exclusion. The cell populations were as follows: Wild-type MEFs lacking E1A (squares); wild-type MEFs expressing E1A (circles); $\mathrm{ARF}^{-1}-\mathrm{MEFs}$ expressing E1A (triangles). N ote that $\mathrm{ARF}^{-1-}$ and $\mathrm{p} 53^{-1-} \mathrm{MEFs}$ lacking $E 1 A$, as well as p53-deficient MEFs expressing E1A, remained viable in adriamycin whether or not they expressed HA-p19ARF (data not shown). (B) lacZ (V, shaded bars) and HA-p19ARF (p19, solid bars) expressing cell populations were treated with $7 \mathrm{~Gy}$ ionizing radiation and cell viability was determined $24 \mathrm{hr}$ later by trypan blue exclusion. The values represent the mean and S.D. of at least three separate populations. MEFs not expressing E1A were resistant to apoptosis under these conditions (data not shown; see also Lowe et al. 1993).

distinct mechanisms, they might act synergistically to enhance cellular chemo- or radiosensitivity. Consistent with this possibility, enforced expression of p19ARF caused a marked increase in apoptosis induced by adriamycin when expressed in either wild-type or $\mathrm{ARF}^{-1}$ MEFs expressing E1A (Fig. 6A). Similar results were obtained following treatment of the cells with ionizing radiation (Fig. 6B). Importantly, the enhanced chemosensitivity produced by enforced $\mathrm{p} 19^{\mathrm{ARF}}$ expression required both E1A and a cytotoxic insult. Hence, wild-type MEFs lacking E1A did not undergo apoptosis following adriamycin treatment and remained insensitive to low doses of the drug upon enforced expression of p19ARF (Fig. 6A, squares). $\mathrm{ARF}^{-1}$ - cells expressing E1A were relatively resistant to drug-induced apoptosis (see also Fig. 4) but were resensitized when ARF was reintroduced (Fig. 6A, triangles). Importantly, introduction of ARF into wildtype cells expressing E1A also enhanced apoptosis in response to low doses of adriamycin (Fig. 6A, circles) or ionizing radiation (Fig. 6B), demonstrating that activa- tion of the ARF-p53 pathway promotes both chemo- and radiosensitivity in the face of an oncogenic signal.

\section{Discussion}

Oncogenic signaling through the ARF-p53 pathway

A variety of cellular stresses activate $p 53$, including DN A damage, hypoxia, and expression of mitogenic oncogenes (for review, see Ko and Prives 1996; Levine 1997). Following D N A damage, p53 becomes phosphorylated by kinases such as DNA-PK or ATM, leading to changes in p53 conformation and activity. In contrast, the E1A oncogene activates p53 through a fundamentally different mechanism, mediated largely by the tumor suppressor p19ARF. Importantly, the DNA damage and E1A signal ing pathways act in parallel: E1A does not produce p53 phosphorylation at serine-15 and DNA damage activates p53 independently of p19ARF (Kamijo et al. 1997). Moreover, p53 is phosphorylated on serine15 following irradiation of ARF-deficient cells (data not shown). Therefore, these data provide a cl ear example of how p53 integrates upstream signaling pathways emanating from diverse stimuli (Fig. 7).

Activation of p53, in turn, can produce several cellular responses, including transient cell-cycle arrest, senescence or apoptosis. Each signaling pathway to p53 may produce subtle differences in p53 activity or function, and perhaps the diversity achieved by a combination of

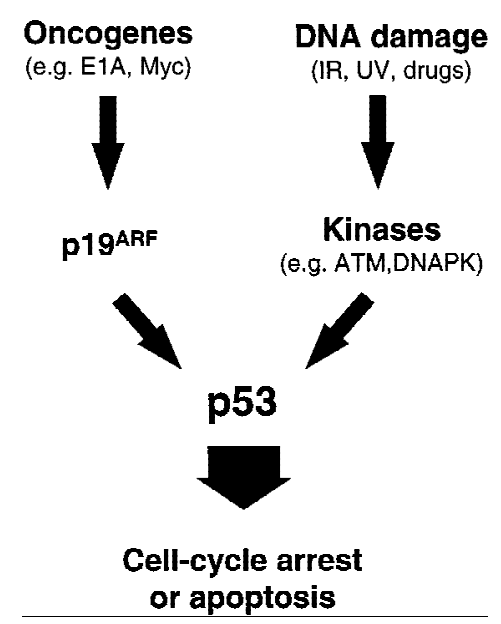

Figure 7. Oncogenes and DNA damage activate p53 through distinct mechanisms. p19ARF acts as an intermediary in p53 activation by mitogenic oncogenes such as E1A and myc. In contrast, activation of p53 following DNA damage involves de novo phosphorylation of p53 on serine-15 (and other residues) by kinases such as the DNA-dependent protein kinase (DNAPK) or the product of the ataxia-telangiectasia gene (ATM) (Shieh et al. 1997; Siliciano et al. 1997). Activation of p53 by oncogenes does not involve phosphorylation on serine-15, and both serine-15 phosphorylation (not shown) and p53 activation (Kamijo et al. 1997) following DN A damage are unimpaired in the absence of ARF. Therefore, the two upstream signal ing pathways to p53 are fundamentally distinct. 
these signals accounts for the complex biology of p53. For example, simultaneous activation of p53 by p19ARF and DN A damage synergize to promote apoptosis in the presence of the E1A oncogene (Fig. 6; see al so Lowe et al . 1993; Samuelson and Lowe 1997). If similar processes occur in human cancer, therapeutic strategies to exploit p19ARF activation may enhance the radiosensitivity or chemosensitivity of p53-expressing tumors.

Like p53, the outcome of p19ARF activation is dependent on cellular context. For example, enforced ARF expression in MEFs induces cell cycle arrest, but cells overexpressing $\mathrm{p} 19^{\mathrm{ARF}}$, together with E1A or Myc (Zindy et al. 1998), undergo apoptosis, which is potentiated by withdrawal of serum survival factors (Evan et al. 1992; Lowe and Ruley 1993; Lowe et al. 1994b). ARF-null MEFs are resistant to both E1A - and Myc-induced apoptosis, bypassing the p53-dependent fail-safe mechanism that normally protects them from these oncogenic signals, and thereby enabling E1A and M yc to function as pure growth promoters. Myc's action as an “immortalizing gene" depends in part on its ability to dismantle the ARF-p53 pathway by selecting for surviving cells that have lost either gene (Zindy et al. 1998). In turn, ARF-null MEFs do not undergo replicative senescence and can be transformed by oncogenic ras al one (Kamijo et al. 1997). We suspect that E1A's immortalizing activity involves similar mechanisms.

Also like p53, ARF has no overt role in normal cell cycle control or development; hence, the physiologic circumstances in which it would become activated to inhibit proliferation or suppress tumor growth were not obvious. Studies here with E1A mutants suggest that p19ARF can be activated to suppress proliferation by the ElA oncogene through mechanisms that correlate with its binding to both $\mathrm{p} 300 / \mathrm{CBP}$ and $\mathrm{Rb}$. These same functions are required for E1A to induce p53 and to promote apoptosis in primary fibroblasts (Samuelson and Lowe 1997) and, remarkably, are al so required for E1A's transforming potential (Whyte et al. 1988b, 1989). Loss of Rb contributes to ARF induction consistent with the possibility that ARF is an E2F-responsive gene (DeGregori et al. 1997). Enforced expression of E2F-1 induces p19ARF, and conversely, ARF-null cells are resistant to E2F-1induced apoptosis (Zindy et al. 1998). Consequently, p19ARF function, like p53, depends upon the mutational status of $\mathrm{Rb}$, and upon both $\mathrm{c}$-myc and ras protooncogene activities. Irrespective of the precise outcome, ARF mutations compromise p53 activation and reduce its ability to counter uncontrolled proliferation.

The data presented here provide additional insights into p53's role in tumor suppression. The predominant view of p53 action centers around its ability to function in the cellular response to DNA damage. Although this stimulus is undoubtedly important for p53's tumor suppressor activity and may contribute to the outcome of cancer therapy (Lowe et al. 1993, 1994a), p53 activation in response to oncogenes provides an alternative pressure to mutate p53 during tumorigenesis (Lowe and Ruley 1993; Lowe et al. 1994b; Symonds et al. 1994). In this view, p53 normally acts to limit the consequences of uncontrolled mitogenesis by promoting cell-cycle arrest or apoptosis, while its loss allows proliferation to continue unabated. The fact that disruption of the ARF-p53 pathway occurs in the majority of human cancers underscores its gl obal importance in suppressing proliferation of oncogene-expressing cells.

\section{Materials and methods}

Cells and cell culture

IM R90 fibroblasts (early-mid passages) expressed the ecotropic retrovirus receptor to allow infection with murine retroviruses (Serrano et al. 1997). Primary MEFs derived from wild-type, p53 ${ }^{-1-}$ (Jacks et al. 1994), and $\mathrm{ARF}^{-1-}$ (Kamijo et al. 1997) day 13.5 embryos were prepared as described previously (Serrano et al. 1997). All cultures were maintained in Dulbecco's modified Eagle's medi um (DM EM ; GIBCO) supplemented with $10 \%$ fetal bovine serum (FBS; Sigma) and 1\% penicillin G/streptomycin sulfate (Sigma). To induce DN A damage, cells were either irradiated with $7 \mathrm{~Gy}$ ionizing radiation using a J.L. Shepherd M ark I irradiator with a ${ }^{137} \mathrm{Cs}$ source or treated with $0.1-0.5 \mu \mathrm{g} / \mathrm{ml}$ adriamycin. To induce p53 independently of DN A damage, cells were treated for $2 \mathrm{hr}$ with $50 \mu \mathrm{m}$ LLnL (Sigma).

\section{Retroviral vectors and infection}

For most experiments, high-titer ecotropic retroviruses were generated by transient transfection using the Phoenix retrovirus packaging system (G. Nolan, Stanford University, CA) as described previously (Serrano et al. 1997). Virus supernatants were used to infect either IMR90 fibroblasts or early-passage MEFs ( $\leqslant$ passage 5 ), and pure populations of E1A-expressing cells were isolated by selection for 2 days in the presence of $2 \mu \mathrm{g} / \mathrm{ml}$ puromycin. Infection was typically between $70 \%$ and $90 \%$ of cells as judged using a control virus expressing $\beta$-galactosidase (not shown). For ectopic expression of p19ARF, a protocol designed to achieve nearly complete infection of cells (Zindy et al. 1998) was used. Retroviral vectors were as follows: LPC, control vector expressing puromycin phosphotransferase (puro); LPC-12S, a 12S E1A CDNA in LPC (M cCurrach et al. 1997); LPC-12S. $\Delta$ N and LPC-12S. $\triangle$ CR2, E1A mutants that fail to associate with p300/CBP or the Rb-related proteins, respectively (Samuelson and Lowe 1997). The retroviral vector encoding HA-p19ARF coexpressed a CD8 cell surface marker (Quelle et al. 1995). pBabePuro-lacZ (a gift of J. M orgenstern, M illenium Pharmaceutical, Cambridge, MA) was used to monitor infection efficiencies and, in some experiments, as a control vector.

\section{Gene expression}

Analysis of p53 phosphorylation on serine-15 was performed exactly as described (Shieh et al. 1997). p53 levels were determined by Western blots using PAb1801 and DO1. p53 immunoprecipitations were performed using pAb 1801 followed by immunoblotting with $\alpha$ p53-P-Ser-15 to identify p53 proteins phosphorylated on serine-15. Western blots to detect p19ARF were performed using antibodies to the carboxyl terminus as described (Kamijo et al. 1998); HA-tagged p19ARF was detected using mAb 12CA5 (1:5000 dilution). All other Western blots were carried out as described previously with minor modifications (Serrano et al. 1997). Whole-cell lysates were derived by lysing cell pellets in SDS sample buffer $(60 \mathrm{~mm}$ Tris- $\mathrm{HCl}$ at $\mathrm{pH}$ $6.8,10 \%$ glycerol, $2 \%$ SDS, 5\% 2-mercaptoethanol). Samples corresponding to $30 \mu \mathrm{g}$ of protein (Bio-Rad protein assay) were 
separated on SDS-PAGE gels and transferred to Immobilon-P membranes (Millipore). p53 was detected using polyclonal antibody CM 5 (1:8000 dilution) (a gift of Peter Hall, Dundee University, UK); M dm2 using mA b 2A 10 (provided by G. Zambetti, St. Jude Children's Research Hospital ); p21 using polyclonal antibody C-19 (1: 500 dilution) (Santa Cruz), and E1A using mAb M 58 (Harlow et al. 1985). Proteins were visualized by ECL (Amersham) and equal sample loading was confirmed by India Ink or Ponseau $\mathrm{S}$ staining of the membrane.

For p53/M dm2 immunoprecipitations, cell pellets were disrupted in ice-cold N P-40 lysis buffer $(50 \mathrm{~mm}$ Tris- $\mathrm{HCl}$ at $\mathrm{pH} 8$, $5 \mathrm{~mm}$ EDTA, $150 \mathrm{~mm} \mathrm{NaCl}, 0.5 \% \mathrm{NP}-40,1 \mathrm{~mm} \mathrm{PMSF}, 0.4 \mathrm{U} / \mathrm{ml}$ aprotinin, $10 \mathrm{~mm}$-glycerophosphate, $1 \mathrm{~mm} \mathrm{NaF}, 0.1 \mathrm{~mm}$ $\mathrm{N} \mathrm{a}_{3} \mathrm{VO}_{4}$ ) on ice for $1 \mathrm{hr}$. Cleared lysates were incubated for $2 \mathrm{hr}$ at $4^{\circ} \mathrm{C}$ with two monoclonal antibodies directed against p53 (pAb 421 and pAb 248) or M dm2 (2A 10), plus $10 \mathrm{mg} / \mathrm{ml}$ BSA. Complexes precipitated with protein A-Sepharose (Amersham) were washed three times with ice-cold N P-40 Iysis buffer. Immunoprecipitates were separated on 7.5\% SDS-polyacrylamide gels and transferred to nitrocellulose. $\mathrm{Mdm} 2$ was detected by immunoblotting using the same antibody, whereas p53 was detected with CM 5 polyclonal antibody as described above.

For $\mathrm{N}$ orthern blots, total RN A was extracted from cells using RN AzolB (Cinna/Biotecx) 1 week postinfection and $30 \mu \mathrm{g}$ was loaded per lane. Fol lowing agarose gel el ectrophoresis and transfer to Hybond membranes (Amersham), blots were hybridized with a ${ }^{32} \mathrm{P}$-label ed probe specific for INK4a exon $1 \beta$ [the portion of the INK4a/ARF locus unique to ARF (Quelle et al. 1995)]. A probe specific for $18 \mathrm{~S}$ rRN A was used to confirm equal loading.

\section{Cell viability and apoptosis}

Cells were distributed into 12 -well plates $\left(10^{5}\right.$ cells $/ 22-\mathrm{mm}$ well) 12-24 hr prior to serum withdrawal, radiation, or drug treatment. Adherent and nonadherent cells were pooled $24 \mathrm{hr}$ after treatment with $\gamma$-radiation, adriamycin, or $0.1 \%$ FBS and analyzed for viability by trypan blue exclusion; $\geqslant 200$ cells were scored for each point. Apoptotic cell death was confirmed by staining with DAPI or FITC-annexin V. Cells $\left(\sim 1 \times 10^{5}\right)$ were fixed in $5 \%$ paraformaldehyde (Mallinckrodt) and DNA was stained with DAPI $(1 \mu \mathrm{g} / \mathrm{ml})$. Images were digitized using a fluorescence microscope coupled to a Photometrics PXL CCD camera (Photometrics Ltd.). For annexin staining, cells were incubated in DMEM with $0.1 \%$ FBS for $18 \mathrm{hr}$, after which adherent and nonadherent cells were pooled. Staining with FITCannexin $\mathrm{V}$ and PI were performed according to the manufacturer's instructions (BioWhitaker) and the cells were analyzed by two-color flow cytometry.

\section{Acknowledgments}

We thank $Y$. Taya for the generous gift of immunopurified antibodies directed against phosphoserine-15 p53 and N. Dyson for p107- and p130-deficient MEFs. We also thank Maria Coronesi and Esther Van de Kamp for technical assistance. E.S. is supported by the Italian Ph.D. program and thanks Dr. G. Biamonti and Professor A. Galizzi for support; G.F. is a Tularik postdoctoral fellow; A.V.S. is supported by an Army Breast Cancer Research fell owship; S.W.L. is supported by a Kimmel Scholarship A ward. This work was funded in part by American Lebanese Syrian Associated Charities of St. Jude Children's Research Hospital, and by grants CA58316 (C.P.); CA56819, CA 71907 (M.F.R.), and CA13106 (S.W.L) from the $\mathrm{N}$ ational Institutes of Health.

The publication costs of this article were defrayed in part by payment of page charges. This article must therefore be hereby marked "advertisement" in accordance with 18 USC section 1734 solely to indicate this fact.

\section{References}

Andree, H.A., C.P. Reutelingsperger, R. Hauptmann, H.C. Hemker, W.T. Hermens, and G.M. Willems. 1990. Binding of vascular anticoagulant al pha (VAC al pha) to planar phospholipid bilayers. J. Biol. Chem. 265: 4923-4928.

Barak, Y., T. Juven, R. Haffner, and M. Oren. 1993. mdm2 expression is induced by wild-type p53 activity. EMBO J. 12: $461-468$.

Barak, Y., E. Gottlieb, T. Juvengershon, and M. Oren. 1994. Regulation of mdm2 expression by p53: Alternative promoters produce transcripts with nonidentical translation potential. Genes \& Dev. 8: 1739-1749.

Debbas, M. and E. White. 1993. Wild-type p53 mediates apoptosis by E1A, which is inhibited by E1B. Genes \& Dev. 7: 546-554.

DeCaprio, J.A., J.W. Ludl ow, D. Lynch, Y. Furukawa, J. Griffin, H. Piwnica-Worms, C.M. Huang, and D.M. Livingstone. 1988. SV 40 large T antigen forms a specific complex with the product of the retinoblastoma susceptibility gene. Cell 54: 275-283.

DeGregori, J., G. Leone, A. Miron, L. Jakoi, and J.R. Nevins. 1997. Distinct roles for E2F proteins in cell growth control and apoptosis. Proc. Natl. Acad. Sci. 94: 7245-7250.

Donehower, L.A., M. Harvey, B.L. Slagle, M.J. McArthur, C.A. Montgomery, J.A. Butel, and A. Bradley. 1992. Mice deficient for p53 are developmentally normal but susceptible to spontaneous tumours. Nature 356: 215-220.

Dyson, N., P.M. Howley, K. M unger, and E. Harlow. 1989. The human papilloma virus-16 E7 oncoprotein is able to bind to the retinoblastoma gene product. Science 243: 934-937.

El Deiry, W.S., T. Tokino, V.E. Velculescu, D.B. Levy, R. Parsons, J.M. Trent, D. Lin, W.E. Mercer, K.W. Kinzler, and B. Vogel stein. 1993. WAF1, a potential mediator of p53 tumor suppression. Cell 75: 817-825.

Evan, G.I., A.H. Wyllie, C.S. Gilbert, T.D. Littlewood, H. Land, M. Brooks, C. Waters, L.Z. Penn, and D.C. Hancock. 1992. Induction of apoptosis in fibroblasts by c-myc protein. Cell 69: 119-128.

Flint, J. and T. Shenk. 1997. Viral transactivating proteins. Annu. Rev. Genet. 31: 177-212.

Graeber, T.G., J.F. Peterson, M. Tsai, K. Monica, A.J. Fornace, and A.J. Giaccia. 1994. Hypoxia induces accumulation of p53 protein, but activation of a G(1)-phase checkpoint by low-oxygen conditions is independent of p53 status. Mol. Cell. Biol. 14: 6264-6277.

Greenblatt, M.S., W.P. Bennett, M. Hollstein, and C.C. Harris. 1994. Mutations in the p53 tumor suppressor gene: Clues to cancer etiology and molecular pathogenesis. Cancer Res. 54: 4855-4878.

Griffiths, S.D., A.R. Clarke, L.E. Healy, G. Ross, A.M. Ford, M.L. Hooper, A.H. Wyllie, and M. Greaves. 1997. A bsence of p53 permits propagation of mutant cells following genotoxic damage. Oncogene 14: 523-531.

Haber, D.A. 1997. Splicing into senescence: The curious case of p16 and p19ARF. Cell 91: 555-558.

Harlow, E., B.R. Franza, Jr., and C. Schley. 1985. Monoclonal antibodies specific for adenovirus early region $1 \mathrm{~A}$ proteins: extensive heterogeneity in early region $1 \mathrm{~A}$ products. J. Virol. 55: 533-546.

Harper, J.W., G.R. Adami, N. Wei, K. Khandan, and S.J. Elledge. 1993. The p21 cdk-interacting protein Cipl is a potent inhibitor of G1 cyclin-dependent kinases. Cell 75: 805-816. 
Haupt, Y., R. Maya, A. Kazaz, and M. Oren. 1997. Mdm2 promotes the rapid degradation of p53. Nature 387: 296-299.

Hermeking, H. and D. Eick. 1994. Mediation of c-myc induced apoptosis by p53. Science 265: 2091-2093.

Jacks, T., L. Remington, B.O. Williams, E.M. Schmitt, S. Halachmi, R.T. Bronson, and R.A. Weinberg. 1994. Tumor spectrum analysis in p53-mutant mice. Curr. Biol. 4: 1-7.

Kamijo, T., F. Zindy, M.F. Roussel, D.E. Quelle, J.R. Downing, R.A. Ashmun, G. Grosvel d, and C.J. Sherr. 1997. Tumor suppression at the mouse IN K4a locus mediated by the al ternative reading frame product p19ARF. Cell 91: 649-659.

Kamijo, T., J.S. Weber, G. Zambetti, F. Zindy, M.F. Roussel, and C.J. Sherr. 1998. Interactions of the ARF tumor suppressor with p53 and Mdm2. Proc. Natl. Acad. Sci. 95: 8292-8297.

Kastan, M.B., O. Onyekwere, D. Sidransky, B. Vogelstein, and R.W. Craig. 1991. Participation of p53 protein in the cellular response to DNA damage. Cancer Res. 51: 6304-6311.

Ko, L.J. and C. Prives. 1996. p53: Puzzle and paradigm. Genes \& Dev. 10: 1054-1072.

Kubbutat, M.H., S.N. Jones, and K.H. Vousden. 1997. Regulation of p53 stability by M dm2. Nature 387: 299-303.

Lane, D.P. and L.V. Crawford. 1979. T antigen is bound to a host protein in SV40-transformed cells. Nature 278: 261-263.

Levine, A.J. 1997. p53, the cellular gatekeeper for growth and division. Cell 88: 323-331.

Linke, S.P., K.C. Clarkin, A. Di Leonardo, A. Tsou, and G.M. Wahl. 1996. A reversible, p53-dependent $G_{0} / G_{1}$ cell cycle arrest induced by ribonucleotide depletion in the absence of detectable DN A damage. Genes \& Dev. 10: 934-947.

Linzer, D.I.H. and A.J. Levine. 1979. Characterization of a 54K dalton cellular SV40 tumor antigen present in SV40 transformed cells and uninfected embryonal carcinoma cells. Cell 17: 43-52.

Livingstone, L.R., A. White, J. Sprouse, E. Livanos, T. Jacks, and T.D. TIsty. 1992. Altered cell cycle arrest and gene amplification potential accompany loss of wild-type p53. Cell 70: 923-935.

Lowe, S.W. and H.E. Ruley. 1993. Stabilization of the p53 tumor suppressor is induced by adenovirus E1A and accompanies apoptosis. Genes \& Dev. 7: 535-545.

Lowe, S.W., H.E. Ruley, T. Jacks, and D.E. Housman. 1993. p53-dependent apoptosis modulates the cytotoxicity of anticancer agents. Cell 74: 954-967.

Lowe, S.W., S. Bodis, A. M cClatchey, L. Remington, H.E. Ruley, D. Fisher, D.E. Housman, and T. Jacks. 1994a. p53 status and the efficacy of cancer therapy in vivo. Science 266: 807-810.

Lowe, S.W., T. Jacks, D.E. Housman, and H.E. Ruley. 1994b. Abrogation of oncogene-associated apoptosis allows transformation of p53-deficient cells. Proc. Natl. Acad. Sci. 91: 2026-2030.

Maki, C.G., J.M. Huibregtse, and P.M. Howley. 1996. In vivo ubiquitination and proteasome-mediated degradation of p53(1). Cancer Res. 56: 2649-2654.

M cCurrach, M.E., T.M. Connor, C.M. Knudson, S.J. Korsmeyer, and S.W. Lowe. 1997. bax-deficiency promotes drug resistance and oncogenic transformation by attenuating p53-dependent apoptosis. Proc. Natl. Acad. Sci. 94: 2345-2349.

Pomerantz, J., N . Schrei ber-Agus, N .J. Liegeois, A. Silverman, L. Alland, L. Chin, J. Potes, K. Chen, I. Orlow, H.W. Lee, C. Cordon-Cardo, and R.A. DePinho. 1998. The IN K4a tumor suppressor gene product, p19ARF, interacts with MDM 2 and neutralizes MDM2's inhibition of p53. Cell 92: 713-723.

Quelle, D.E., F. Zindy, R.A. Ashmun, and C.J. Sherr. 1995. AIternative reading frames of the IN K4a tumor suppressor gene encode two unrelated proteins capable of inducing cell cycle arrest. Cell 83: 993-1000.
Querido, E., J.G. Teodoro, and P.E. Branton. 1997. Accumulation of p53 induced by the adenovirus E1A protein requires regions involved in the stimulation of DNA synthesis. J. Virol. 71: 3526-3533.

Ross, W.E. and M.O. Bradley. 1981. DNA double-stranded breaks in mammalian cells after exposure to intercalating agents. Biochim. Biophys. Acta 654: 129-134.

Samuelson, A.V. and S.W. Lowe. 1997. Selective induction of p53 and chemosensitivity in RB-deficient cells by E1A mutants unable to bind the RB-related proteins. Proc. Natl. Acad. Sci. 94: 12094-12099.

Serrano, M., G.J. Hannon, and D. Beach. 1993. A new regulatory motif in cell-cycle control causing specific inhibition of cyclin D/CDK4. Nature 366: 704-707.

Serrano, M., A.W. Lin, M.E. McCurrach, D. Beach, and S.W. Lowe. 1997. Oncogenic ras provokes premature cell senescence associated with accumulation of p53 and p16IN K4a. Cell 88: 593-602.

Shieh, S.Y., M. Ikeda, Y. Taya, and C. Prives. 1997. DN A damage-induced phosphorylation of p53 alleviates inhibition by MDM 2. Cell 91: 325-334.

Siliciano, J.D., C.E. Canman, Y. Taya, K. Sakaguchi, E. A ppella, and M.B. Kastan. 1997. DN A damage induces phosphorylation of the amino terminus of p53. Genes \& Dev. 11: 3471-3481.

Symonds, H., L. Krall, L. Remington, M. Saenzrobles, S. Lowe, T. Jacks, and T. Vandyke. 1994. p53-dependent apoptosis suppresses tumor growth and progression in vivo. Cell 78: 703-711.

Wagner, A.J., J.M. Kokontis, and N. Hay. 1994. Myc-mediated apoptosis requires wild-type p53 in a manner independent of cell cycle arrest and the ability of p53 to induce p21waf1/ cipl. Genes \& Dev. 8: 2817-2830.

Weinberg, R.A. 1995. The retinoblastoma protein and cell cycle control. Cell 81: 323-330.

Werness, B.A., A.J. Levine, and P.M. Howley. 1990. Association of human papillomavirus types 16 and 18 E6 proteins with p53. Science 248: 76-79.

Whyte, P., K.J. Buchkovich, J.M. Horowitz, S.H. Friend, M. Raybuck, R.A. Weinberg, and E. Harlow. 1988a. Association between an oncogene and an anti-oncogene: The adenovirus E1A proteins bind to the retinoblastoma gene product. Nature 334: 124-129.

Whyte, P., H.E. Ruley, and E. Harlow. 1988b. Two regions of the adenovirus early region $1 \mathrm{~A}$ proteins are required for transformation. J. Virol. 62: 257-265.

Whyte, P., N.M. Williamson, and E. Harlow. 1989. Cellular targets for transformation by the adenovirus E1A proteins. Cell 56: 67-75.

Wu, X., J.H. Bayle, D. Olson, and A.J. Levine. 1993. The p53mdm-2 autoregulatory feedback loop. Genes \& Dev. 7: 1126-1132.

Xiong, Y., G.J. Hannon, H. Zhang, D. Casso, R. Kobayashi, and D. Beach. 1993. p21 is a universal inhibitor of cyclin kinases. Nature 366: 701-705.

Yin, Y., M.A. Tainsky, F.Z. Bischoff, L.C. Strong, and G.M. Wahl. 1992. Wild-type p53 restores cell cycle control and inhibits gene amplification in cells with mutant p53 alleles. Cell 70: 937-948.

Zhang, Y., Y. Xiong, and W.G. Yarbrough. 1998. ARF promotes M DM 2 degradation and stabilizes p53: ARF-IN K4a locus deletion impairs both the $\mathrm{Rb}$ and p53 tumor suppression pathways. Cell 92: 725-734.

Zindy, F., C.M. Eischen, D.H. Randle, T. Kamijo, J.L. Cleveland, C.J. Sherr, and M.F. Roussel. 1998. MYC-induced immortalization and apoptosis targets the ARF-p53 pathway. Genes \& Dev. (this issue). 


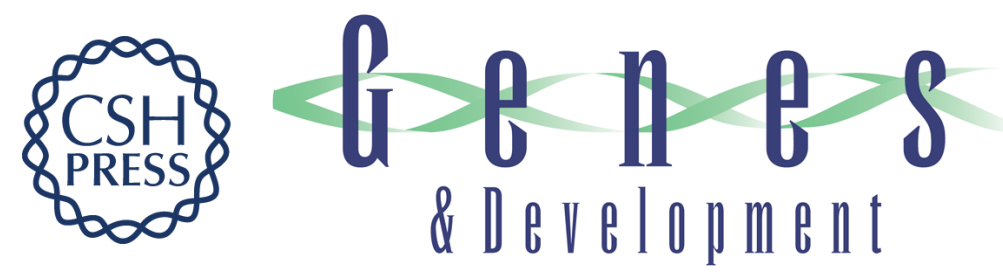

\section{E1A signaling to $p 53$ involves the p19ARF tumor suppressor}

Elisa de Stanchina, Mila E. McCurrach, Frederique Zindy, et al.

Genes Dev. 1998, 12:

Access the most recent version at doi:10.1101/gad.12.15.2434

References This article cites 56 articles, 25 of which can be accessed free at: http://genesdev.cshlp.org/content/12/15/2434.full.html\#ref-list-1

License

Email Alerting Receive free email alerts when new articles cite this article - sign up in the box at the top Service right corner of the article or click here.

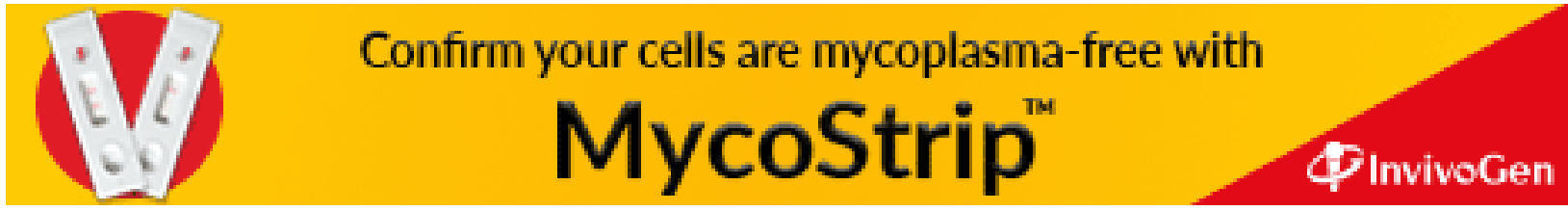

